\title{
Assessing Tourists’ Perceptions of Climate Change on Mountain Landscapes
}

\author{
BRUCE PRIDEAUX, ALEXANDER COGHLAN and KAREN MCNAMARA
}

\begin{abstract}
The increasing popularity of mountains as a tourism resource has coincided with growing concerns about the probable impact of climate change on sensitive mountain ecosystems and the long-term sustainability of these ecosystems. This paper outlines and tests a six-step model that synthesizes scientific research into the probable impacts of climate change on mountain ecosystems with tourism research that evaluates how tourists are likely to respond to visual changes in mountain landscapes. The model was tested in the Wet Tropics rainforests of Queensland, Australia and found to have a predicative capability on possible tourist response to climate change impacts in mountain destinations.
\end{abstract}

Keywords: climate change; mountains; sustainability; wet Tropics rainforest; adaptation; landscapes; climate change impact model.

BRUCE PRIDEAUX is Professor at the School of Business, PO Box 6811, James Cook University, Cairns, Queensland, 4870, Australia. e-mail: bruce.prideaux@jcu.edu.au ALEXANDER COGHLAN is at the School of Business, PO Box 6811, James Cook University, Cairns, Queensland, 4870, Australia. e-mail: alexandra.coghlan@jcu.edu.au

KAREN MCNAMARA is at the School of Business, PO Box 6811, James Cook University, Cairns, Queensland, 4870, Australia. e-mail: karen.mcnamara@jcu.edu.au

\section{Introduction}

Ultimately, climate change will force a revision of the way we view the world, or in the language of Urry (1990), the way we gaze on the landscapes that constitute the tourist experience. The process of revision will for the most part be on-going, generally slow and largely unrecognized on a year-on-year basis. There will be a strong generational element in this process. Just as the world of the reader's grandparents was vastly different from the readers' own world, so to will the climate-modified world of the yet unborn children of Generation $\mathrm{Z}$ be vastly different from our own experience of the world. The process of adapting to these modified landscapes will become an important issue for the tourism industry, consumers and policy-makers. In ecological terms, for example, questions about the extent to which current ecosystems should be preserved must be addressed. From a protected area perspective, there may be a need to adjust boundaries as the spatial organization of protected ecosystems change or migrate. The solutions to questions of this type will shape how future generations of tourists use these resources. Surprisingly, the tourism literature has been and view slow to draw on the extensive scientific literature on climate change to develop a tourism view on the issue.

Mountains are dominating features of the landscape, occupying approximately 24 per cent of the Earth's surface (Marston 2008) and often located in remote and peripheral regions. They are also home to about 20 per cent of the world's population (Marston 2008), are places of great beauty, and often contain sensitive and unique ecosystems with many rare and endangered species. Traditionally, human use of mountains has included hunting for food and sport, mining, forestry, agriculture, grazing, religious sanctuaries and as places of refuge for marginalized or persecuted groups (Zurickand Karan 1999). More recently, tourism has emerged as a new use, supplementing, or in some cases replacing previous uses. The attraction of mountains as a location for tourism activity may be categorized as recreational, for health (spas) and for scenic values. 
In opening mountain regions for mass and niche forms of tourism, modern transport technologies have largely conquered the age old travail of mountain travel, reduced the sense of remoteness and conquered the impediment of periphery by providing high speed rail, road links and air links. However, tourist activity has introduced new pressures on both human and biological communities in mountain region (Beniston 2003). These dangers include adverse impacts on fragile environments, introduction of invasive species, pressure on mountain heritage values and local cultures, and more recently, the dangers posed by climate change (IPCC 2007; Beniston 2003). This paper focuses on climate change as the factor that poses one of the greatest threats to the long-term ecological and economic sustainability of mountain tourism in future decades. To identify the various linkages between climate change and its effects on tourism usage of this landscape, this paper outlines the Climate Change Impact Model (CCIM). The model is tested by applying it to the World Heritage-listed mountain rainforests of the Wet Tropics, Australia.

\section{Tourism in Mountain Regions}

Society's views on mountains have shaped the way they have been used and the manner in which their inhabitants and resources have been treated. In many early European traditions, mountains were seen as fearsome places (Bernbaum 1997), the home of dragons, trolls, wild ferocious animals and unfriendly or even dangerous inhabitants. For these reasons extensive recreational activity in mountain regions did not commence until the mid-18th century (Godde et al. 2000). In Asia, mountains were seen in a wider variety of contexts: as places of worship and in some areas as gods (Mason 1999), as evil places inhabited by dragons, and as places of retreat. Mt Gumgang, North Korea, for example, has a long history as a place of worship and retreat (Kim and Prideaux 2003). In the more recent colonial era, the British and French built hill stations as summer retreats for expatriate officials, settlers and members of the military (Michaud and Turner 2006).

The development of organized European mountain tourism commenced in the mid-18th century when poets, artists, writers and members of the aristocracy began visiting mountains (Godde et al. 2000) and communicating their experiences with others. Artists were an important part of the process of interpretation of landscapes and wilderness experiences. Artists were an important part of the process of interpreting landscapes and wilderness experiences. Mountain wilderness move formed by replacing the chaos of nature with order and symmetry. In a similar manner, poet romanticized mountain landscapes with poetic devices painting wood pictures of nature tamed. Landscapes are an important component of the mountain experience and while there have been numerous studies undertaken on various aspects of landscapes (Buzinde et al. 2010), the impact of climate change on mountain landscapes has yet to be investigated.

Mountaineers were probably the first identifiable visitor segment in Europe's mountains (Beedie and Hudson 2003) and engaged in forms of activities that would now be defined as adventure tourism, although, in all probability, they did not see themselves as tourists. By the $19^{\text {th }}$ century, freed of earlier notions of mountains as forbidding and unsafe places, the attitude of Europeans began to change as many mountain regions were opened for recreational pursuits, including climbing, relaxation, spas and walking. A romantic view of mountains emerged in European society where exploration, journey and adventure became important qualities. Thomas Cook, one of the world's first travel companies, offered a package tour to Switzerland in 1863, which, with the later developments of cableways such as the one established in Rigi in 1873, laid the foundation for the emergence of the Swiss mountain resort sector. Later, winter sports commencing with skiing, were added to the range of ever-increasing outdoors activities. The European view of mountains as places for recreation and leisure activities was adopted in North America within a few decades but had to wait to the post-colonial period before being adopted in Asia. 
In recent decades, mountain tourism activity has grown enormously and now encompasses mountain destinations in temperate as well as equatorial regions and in most continents. The level of demand can be described as a function of the quality of the landscape, the variety of activities offered, infrastructure standards and the ease of access. While relatively little research has been undertaken into the role of landscapes and infrastructure in demand for mountain tourism experiences, there is a growing understanding of the role of activities. In mountain settings, activities range from winter snow sports in alpine regions to a growing range of summer adventure activates in both alpine and non-alpine regions. The growth in demand is demonstrated in the US where just four Rocky Mountains national parks recorded 17\% of all visits to US National Parks in 2003 while in Canada 65\% of all visits to national parks occurred in the Rocky Mountains (Scott et al. 2007). Access is also an important issue, but is not addressed in this paper.

The change in status of mountains that paralleled their development as tourism resources has a paradoxical quality. Places once feared have metamorphosed into places of desire and extravagance but as the use of mountain areas for recreation has increased, so have the dangers that this form of use will sow the seeds for the destruction of the very qualities that are found to be so desirable (Prideaux 2009). In the past, and even in the present, tourism development has occurred with little reference to ecological impacts (Holden 1998) despite the fragility and sensitivity of these ecosystems. Given that many popular mountain resorts rely on the quality of their landscapes as a key selling point, this is surprising.

The growing demand for leisure and recreation has underpinned the rapid development of mountain destinations and while this has brought benefits to many areas, it has also created concerns about long-term ecological sustainability and possible impacts on traditional mountain communities and their unique culture and heritage (Pfisher 2000). Rapid development has caused a range of problems, some of which are only now being recognized as threats to long-term sustainability. A review of the literature indicates that major issues faced by mountain tourism include accessibility (Prideaux 2009), sustainability (Godde et al. 2000), seasonality (Godde et al. 2000), mountain cultures and heritage (Nyaupane et al. 2006), urbanization (Edensor 1988; Shah and Nagpal 1997), and, more recently, climate change (IPCC 2007). In the last two decades and, more specifically, in the first decade of the 21 st century there has been growing recognition that one of greatest dangers to mountain tourism is climate change (IPCC 2007; Scott et al. 2003; Marston 2008; Beniston 2003).

\section{Climate Change}

As Becken and Hay (2007:7) note there are 'multiple interactions between tourism and climate. Climate is both a resource for the tourism experience and a risk'. Of all the issues faced by mountain destinations, climate change is one of the most serious and is likely to have the greatest long-term impact. Impacts will be caused by changing weather patterns and, in some cases, fire events causing large scale and irreversible changes to plant and animal communities and the scenic values they provide. The IPCC (2007) report expressed concern about the future viability of low altitude snow fields, receding glaciers and possible large scale loss of biodiversity as global temperatures increase.

In recent years, the tourism and other literatures have begun to comment on the challenge of climate change, with an increasing number of papers and books (e.g., Becken and Hay 2007; Hall and Higham 2005) being published supported by the emergence of specialized climate change and tourism conferences and calls for the establishment of a specific climate change research agenda (Dubois and Ceron 2006). Scientific interest in climate change has a much longer history and it is this literature that first alerted tourism researchers to the dangers posed by climate change. The extent of possible impacts are now emerging and have been clearly articulated in major reports that 
include IPCC reports (1990, 1995, 2001, 2007) and the Stern Report (2006). The 2007 IPCC Report (IPCC 2007:1) in particular noted: 'Warming of the climate system is unequivocal, as is now evident from observations of increases in global average air and ocean temperatures, widespread melting of snow and ice and rising global average sea level'. Further, the report (IPCC 2007) warned that many natural systems are or will be affected by regional climate change as temperatures increase. Commenting on the possible impacts of climate change, a number of authors (Matzarakis 2002; Braun et al. 1999) and reports (UNTWO2007) have noted that the impacts are likely to be severe and long-lasting. It is also likely that the impacts will generate large-scale disturbances in many tourism markets (Prideaux et al. 2009; Gossling and Scott 2008; Gossling and Svensson 2006; Hamilton et al. 2005; Loman-Scalon 2006), particularly those that rely on distant generating markets (Dwyer and Forsyth 2008; Simmons and Becken 2004).

The expected impacts on mountain regions include retreating glaciers (Hall and Farge 2003), reduced snowfall in some areas, shifts in the range of some species (Williams et al. 2001; Parmesan and Yohe2003), longer and more severe droughts, flooding, reduced summer flows of snow-feed rivers in many areas, more intense fire events (Scott et al. 2003), more intense weather events, drying of some areas and increases in perception in others. Already, some of these changes are beginning to occur in low altitude ski resorts that are now experiencing poor, late and short snow seasons (Koenig and Abegg 1997; Elasser and Burki 2002; Scott et al. 2003; Becken and Hay 2007). According to modelling by Koenig and Abegg (1997) a $2^{0} \mathrm{C}$ increase in temperature will reduce the number of ski resorts having reliable snowfall from $85 \%$ to $63 \%$. Changes of this nature will reduce the viability of low altitude ski resorts, forcing them either to shut permanently, diversify into summer activities or undertake artificial snow making, although this latter response may not be sustainable in the longer term. In other areas, rapidly retreating glaciers have changed the scenic landscape (Hall and Farge 2003) to the extent that tourism demand may fall (Scott 2005).

\section{Mitigation and Adaptation}

To combat climate change, the scientific community has endorsed mitigation and adaptation as strategies to deal with the problem. Mitigation, defined as an overall reduction in the global level of emission of harmful greenhouse gases, can only be achieved if a multilateral approach is taken (Fry 2008). Given the difficulty involved in achieving an effective global political response to reducing emissions and the uncertainty surrounding the rate at which global warming will occur in coming decades, the success of mitigation as a strategy to deal with climate change appears doubtful, at least in the short term. If mitigation fails, adaptation, described as processes whereby human systems adjust to the new conditions created by climatic change, will become necessary. Adaptation includes strategies to adjust infrastructure, methods of operations and activities to cope with changed climatic conditions, including sea level rise. For mountain destinations exposed to adverse impacts of climate change, adaptation will become a high priority. To date, little research has been undertaken into the time-frames that may be required for the adoption of strategies to cope with climate change, possibly because not all destinations recognize the need for adaptation or because the necessary resources have not been allocated. The Climate Change Impact Model outlined later in this paper offers one method for developing adaptation strategies.

Adaptation has two aspects, a biological aspect and a human aspect. The biological aspect has several factors, including the ability of species to alter their physiology enabling them to adjust to change in a process known as acclimatization. The second process occurs when populations adapt to new conditions by natural selection (Krebs 2008). On a biological time-scale the rate of climate change is likely to be so rapid that natural selection is unlikely to occur in most species, forcing them to migrate or face local extinction. Unlike humans, acclimatization of plant and animal communities is also unlikely to occur given the extent of the changes predicted to occur. What is more 
likely is that biological adaptation will result in changes in the species mix of plant and animal communities to create new ecosystems that suit the changed conditions either through pioneering species replacing dominant species or thermophilious (heat loving) species replacing current dominant species (Keller et al. 2000). Human adaptation will focus on redesigning infrastructure to cope with changed climatic, wind and fire conditions.

The impact on mountain tourism can be viewed on two impact scales: a global scale, and a destination scale. On the global scale, human-generated climate change poses a range of problems primarily created by increasing temperatures causing changes in weather patterns, which will have a cascading effect on all ecosystems (Fry 2008; IPCC 2007; Stern 2006). Only a reversal of global emissions of greenhouse gases through globally coordinated mitigation strategies will reduce the size and extent of change to mountain ecosystems. Given the failure of the 2009 United Nations Climate Change Conference (Copenhagen Summit) to adopt specific targets for reduction of greenhouse gases, it may be some time before the tourism industry will be forced to adopt mitigation strategies to reduce emissions.

Adaptation strategies will become critical if global efforts to reduce greenhouse emissions fail or are delayed, as now appears to be the case. At the destination level, there is a need to develop adaptation strategies to minimize adverse impacts. However, before adaptation strategies can be developed, the likely impacts of climate change for each one degree rise in temperature need to be identified. This requires an enhanced investment in scientific research, a more effective discussion between scientists, managers and tourism operators, a willingness of the supply side to respond proactively, and acceptance by consumers that they have an important role to play in both mitigation and adaptation.

From a consumer perspective, there will first have to be recognition that climate change poses a serious problem for human welfare, followed by individuals accepting that they are a central part of the problem. Once consumers accept the position that they are part of the problem, a personal behavioural tipping point will be reached where there will be an increased willingness to accept that they must become part of the solution (Prideaux et al. 2009; McKercher et al. 2010). However, becoming part of the solution will require significant changes in lifestyles and this may impact on patterns of travel consumption.

\section{Destination Scale Impacts}

On a destination scale, the impact of climate change is likely to cause substantial changes to local ecosystems (Walther et al. 2002) and as these changes occur the amenity of particular regions for tourism use is likely to change. Impacts may be described under four categories: changes to local ecosystems; changes to local weather patterns defined as the daily and annual pattern of precipitation, wind and humidly; changes in human use, activity and consumption as weather patterns change local ecosystems; and finally, economic impacts that can be measured as impacts to the regional economy and effects on ecosystem services (Stern 2006).

Climate change will also affect recreational use and scenic values in many mountain destinations. Changes to local weather patterns may disrupt recreational activities such as winter snow sports, while changes in local ecosystems will impact on scenic values. Already, some changes of the type predicted by the IPCC (2007) have begun to occur in low altitude snow resorts in Swiss Alpine areas (Burki et al. 2007) and in areas where glaciers are in retreat. 
Climate change induced modification of local weather patterns may also affect the perceived attractiveness of specific mountain regions. In the Rocky Mountains National Park (Canada), Richardson and Loomis (2004) found that increased temperatures throughout the year was likely to attract a larger number of visitors with estimated increases of 7-12\% predicted for the 2020s. Similarly, Scott et al. (2007) found that visitor numbers were likely to increase in the Watson Lakes National Park, Canada.

At the ecosystem level, plant and animal communities will have to contend with increasing temperatures, changes in seasonal weather patterns, changes in precipitation and in some areas an increase in the number and intensity of fire events (Parmesan and Yohe 2003). This is likely to have a number of impacts, ranging from local species extinction to colonization by pioneer species as fauna and flora look for new areas that suit their particular biological needs (Walther et al. 2002). For example, in their study of the Glacier National Park (Montana, USA), Hall and Frage (2003) found that species reorganization would occur as the ecosystem experiences both elevational and latitudinal changes leading to forest advance up-slope by 20 metres per decade through to 2050. Williams et al. (2003) found that in the Wet Tropics rainforests of Australia, climate change would produce significant elevational and altitudinal changes in ecosystem composition.

To date, much of the debate in the tourism literature has focused on translating the results of scientific-based climate change research into assessments of its impact on specific geographical regions, and how the tourism industry may respond with a particular emphasis on the supply side (Turton et al. 2009). Less research has been undertaken into possible impacts on demand and how consumers will respond to changes in local weather patterns and ecosystems. The sequence of research to date can be described as science alerting the tourism industry to possible impacts, to which industry and government have responded by funding research into implications for the supply side, with a relatively small number of studies into impacts on consumers.

Given the climate related issues that many mountain regions will face in coming decades, there is an urgent need for closer collaboration between science and the tourism industry. A specific outcome of such collaboration should be mechanisms that allow the findings of the scientific community to be translated into assessments of the possible impacts on mountain landscapes and ecosystems. An output of this nature is a prerequisite for further research into how consumers will respond to climate change induced impacts and into possible adaptation measures. The following discussion seeks to address this issue by developing and testing a climate change impact model that can be used to inform the tourism industry on the type of changes that may occur.

\section{Aim of Research and Methodology}

The aim of this research was to develop a model that may be used to assess the impact of climate change on mountain tourism destinations. The model was developed from a post-constructivist perspective based on informal discussions over a long period of time with managers, planners, scientists and tourism operators working in the Wet Tropics rainforest area of Queensland, Australia. In addition to these discussions, the model reflects the synthesis of the outputs of a number of scientific investigations into the impact of climate change on the region (Williams et al. 2003; WTMA 2008) with tourism research undertaken by Prideaux and Falco-Mammon (2010). This approach differs from previous research approaches, some of which have used scenarios and open-ended questions to elicit views on future tourist perceptions of demand for travel to climate change-affected regions. 
A mix of qualitative and quantitative methods was used with data drawn from both social science and scientific research. To test the capacity of the model to be used as an analytical tool, it is applied to Wet Tropics rainforests of Australia. The Wet Tropics was selected as a representative mountain region that is facing significant impacts from climate change. Once successfully tested, the model may be applied in other mountain destinations with modifications that take into account differences in ecosystems, land use patterns and tourism activity.

\section{Proposed Climate Change Impact Model}

Figure 1 integrates science, supply (defined as landscapes, ambient temperature and scenic views) and demand (for tourism experiences) into a six-stage Climate Change Impact Model that can be used to assess the relationships between each stage of the model through to assessing possible adaptation strategies. In the form outlined in Figure 1, the CCIM is descriptive and designed to identify linkages that might otherwise go unnoticed. From this perspective, the model has a capacity to be used as an aid in planning. The concept underlying the model is that changes to climate will result in changes to ecosystems, the patterns of human settlements, economic patterns, agricultural systems, and, in this case, the tourism system. Conceptually, the model is based on two sets of theory: a standard economic demand and supply model where a change in supply leads to a change in demand, and the concept of consumer push and destination pull factors. In this paper the focus of the discussion centres on the former leaving it to a later paper to explore the issue of push and pull in greater detail. In a given tourism system, various supply-side inputs are required to create a touristic experience that is subsequently marketed to and consumed by tourists. Inputs typically fall into four categories: local weather patterns; the natural resource (landscapes, scenic views, flora and fauna, and weather); infrastructure constructed to support tourism (including accommodation, transport networks, walking tracks and other services), and management of the resource. Together, these inputs constitute the characteristic product of a mountain destination. The consumption of this product by consumers may be measured as demand, which is described as a function of the quality of the inputs and successful marketing of the destination. If the quality of inputs changes, the level of demand can be expected to change. In the case of climate change, the quality of the inputs are likely to change, causing a shift in the level of demand. In push-pull terms, disruption to the push-pull equilibrium may occur either as a consequence of destination pull factors being disrupted by climate change, or consumer push factors being altered by increasing concern about climate change.

In Figure 1, the first-order impacts of climate change are shown as changes to temperature (mean yearly average temperature variations based on day and night and by season), changes in precipitation (rain, snow, fog, clouds), wind (including daily wind speeds and wind events such as wind storms), fire events and changes in sea level. Collectively, these impacts cause ecological changes, including loss of biodiversity, changes in the composition of flora and fauna of local ecosystems, and reduced sustainability, and are shown as Stage 2, Biological/physical impacts. The biological and physical impacts may cause visible changes to the natural ecosystem which in turn may affect tourism demand. For example, a reduction in precipitation has led to the retreat of many glaciers causing changes to the quality of the scenic views promoted by mountain destinations. Changes of this nature are illustrated by Stage 3, Changes to the mountain environment. Local changes in climate may affect the physical resources that define the nature and quality of the environment which is often the major appeal of mountain tourism (Scott et al. 2007). Impacts can range from retreating glaciers to loss of snow, increases in average yearly temperature and significant changes in plant communities, loss of iconic animal species, changes in settlement patterns and changes in agricultural systems. Changes of the nature shown in Stage 3 will have a direct bearing on aesthetic values, which may reduce the perceived attractiveness of a specific region (Elsasser and Burki 2002) from a tourism perspective. Changes that are observed in Stage 3 will lead to a series of impacts on all human and natural systems that comprise mountain regions and are shown as Stage 4, Impacts. In Figure 1, the impact on tourism is shown as Stage 4a Tourism impacts. From a tourism perspective changes in weather may have either negative or positive impacts, and, in some areas, increased temperatures may generate increased demand (Scott et al. 2007; Richardson and Loomis 
2004).

The impacts shown at Stage 4a may be either negative or positive and are illustrated in Stage 5, Possible Tourism outcomes. Negative outcomes may include reduced demand, reduced investment, the need to develop alternative markets and closure of some destinations. Positive outcomes may result in increased tourism flows. Strategies to adapt to climate change impacts are illustrated as Stage 6, Adaption Strategies.

The major utility of the model is its ability to illustrate the linkages between the various elements of the physical and human systems operating in mountains. For example, if research indicates that temperatures are rising, possible impacts can be traced from initial biological and physical impacts through to tourism outcomes and adaption strategies. Changes of this nature will affect the nature of the tourism experience and the level of enjoyment experienced by visitors. While the CCIM is primarily designed to show linkages and cause-and-effect loops, it can also be used to measure the scale of impact. At each step of the model, there is potential to measure the nature and size of impacts through a range of cause-and-effect relationships. In Stages 1 and 2, for example, a range of science-specific methods are able to be used to measure specific factors such as change in temperature, precipitation, wind and fire. These findings may then be used to show possible and probable changes in Stage 2 factors (loss of biodiversity, ecosystem changes, physical changes and reduction in sustainability). At Stage 5, social science research methods including scenarios and surveys, may be used to measure the extent of possible changes in consumer demand, which can also be understood in terms of push-pull perceptions.

Once the possible outcomes on tourism have been identified in Stage 5, it becomes possible to examine strategies (Stage 6, Adaptation Strategies) that may be used to cope with the changes identified in Stage 2. When considering the strategies that need to be implemented at this stage, there is also a need to consider resilience factors. In the following case study, the possible impacts of climate change on the Wet Tropics rainforests in Queensland, Australia are first outlined, followed by an assessment of possible impacts on tourism, based on data collected by Prideaux and Falco-Mammone (2010).

\section{The Study Region}

The Wet Tropics rainforests are located in the Great Dividing Ranges in the section that runs from Cooktown in the north to Paluma in the south. Much of the rainforest is composed of remnant rainforest that was declared as a World Heritage Area in 1988. Measuring 894,420 hectares in size, the rainforest contains a third of Australia’s 315 mammal species, over a third of the nation’s freshwater fish species, nearly half of Australia’s birds species and a quarter of Australia's frogs, in addition to at least 3500 species of insects (Wet Tropics Management Authority 2007). A large proportion of the 3,000 plant species found in the region have long evolutionary histories and at least 50 species of primitive flowering plants are found only in this rainforest. The significance of the Wet Tropics' biological diversity was recognized by the region's inclusion in The Global 200 List, which highlights the world's most diverse and outstanding natural areas.

Research by Bentrupperbaumer et al. (2004) found that about 4.65 million visits were made to the forest during 2001/ 2002, with 75 per cent of visits occurring at 15 locations. The tourism industry’s contribution to the regional economy was estimated to be AU\$ 426 million in 2007 (Prideaux and Falco-Mammone 2007). Currently, 180 visitor sites are located throughout the Wet Tropics and 94 of them have infrastructure for visitors. A number of commercial tourist attractions are also located in the rainforest and offer a large range of nature-based activities, including interpretive guides, walking and biking trails, swimming, spotlighting, bird watching, rafting and 
camping.

The Wet Tropics World Heritage area is managed by the Wet Tropics Management Authority (WTMA) and is jointly funded by the Queensland State Government and the Australian Federal Government. The WTMA is responsible for policy development that has the overriding aim of preserving the forest while also allowing some development including tourism use. The Wet Tropics bioregion has a mosaic of landholdings, including national park (64.2\%), leasehold (8.9\%), and freehold (1.9\%) (Wet Tropics Management Authority 2007).

\section{Application of the Climate Change Impact Model}

In the following discussion, the model is tested by applying it to the Wet Tropics rainforest region. The underlying assumption in the following discussion is that tourism demand in the Wet Tropics is a function of attractive landscapes, adequate infrastructure, interesting activities, ease of access and marketing success. If the quality of any of these factors changes because of climate change, it can be anticipated that there is a potential for changes in the patterns of how tourists view and use the landscape. The discussion examines each element of the model to test the postulated linkages and relationships.

\section{Climate Change Effects (Stage 1)}

The findings of recent CSIRO (Commonwealth Scientific and Industrial Research Organization) climate modeling (Suppiah et al. 2007) indicates the extent of changes that may occur to the study region's weather based on low and high scenarios. By 2030, temperatures will

increase between $0.5^{\circ} \mathrm{C}$ for low emission scenarios to $1.4^{\circ} \mathrm{C}$ for high emissions scenarios rising by 2070 to $1.0^{\circ} \mathrm{C}$ for low emission scenarios to $4.2^{\circ} \mathrm{C}$ for high emission scenarios. Rainfall variability is expected to be higher, and, overall, the region will be drier and be characterized by a longer and drier dry season. There is also likely to be an increase in El Nino events resulting in lowered rainfall. By 2030, changes in rainfall will be of the order of $-6 \%$ to $+5 \%$ annually rising to $-19 \%$ to $+14 \%$ annually in 2070 . The dry season is likely to be between $-16 \%$ to $+2 \%$ drier by 2030 rising to $-50 \%$ to $+7 \%$ in 2070 . In addition to changes in precipitation and temperatures, the CSIRO models indicate an increase in the frequency and severity of extreme weather events including cyclones, heat waves, floods and droughts. Of particular concern for already threatened mountain top ecosystems is the possibility that the altitude of the cloud base will rise, inhibiting the ability of the region's upland rainforest to cloud strip for water and reducing the rate of transfer of water from the atmosphere into the region's terrestrial systems (Still et al. 1999).

\section{Biological/Physical Impacts (Stage 2)}

The location, extent and composition of the existing rainforest is largely determined by rainfall, temperature, seasonality (WTMA 2008) and soil types. Rainforest species live within a narrow temperature range and changes in temperature will impact on biodiversity at all levels of organization, including biological, ecosystem, ecological through to population levels (WTMA 2008). Recent research (Krockenberger et al. 2003; Hilbert et al. 2001; Williams et al. 2003) shows that changes in temperature will have significant impacts on the region's plant and animal communities. Biological impacts, for example, include the responses of species in the timing of their life-cycle, including fruiting and flowering (Root et al. 2003) as well as changes in species' abundance (Krockenberger 2002) and in the range of species (Hilbert et al. 2001; Williams et al. 2003). Changes at the ecosystem level will include changes in nutrient cycling, water cycles and changes in predator-prey and parasite-host relationships. At the ecosystem services level, changes will occur in areas that include pest control, pollination, water supply and carbon sequestration. 
Populations of many species will be affected and changes will occur in their abundance and distribution (Williams et al. 2003; Beier and Noss 1998) primarily because of individual species' responses to warmer and drier moisture conditions. For example, changes in seasonality may result in shorter growing seasons for some rainforest fruit trees, which will affect food supply security for dependent animals and birds. Changes of this nature increase the risk of extinction of species that are already vulnerable as a consequence of their limited range, specialized habitat requirements, limited dispersal ability and low genetic diversity (WTMA 2008). As temperatures increase, vulnerable species will begin to shift in range on both latitudinal and altitudinal scales (Hilbert et al. 2001; Williams et al. 2003). Unfortunately, for species seeking altitudinal shift, the relatively low altitudes of the mountains of the Wet Tropics will reduce their changes for survival. In Figure 2, Williams et al. 2003 illustrates the potential impact on the biodiversity of the Wet tropics as temperatures increases in graduations of $1^{0} \mathrm{C}$.

As a result of these changes, native species will become vulnerable to changes in weather through longer dry seasons interrupting seasonal patterns of food production and reproduction. As temperatures increase, the likelihood of species migrating will increase and existing ecosystems will face a variety of new predators, pathogens (Walther et al. 2002; Dukes 2003) competitors and diseases against which they may have no natural defenses (WTMA 2008). In some cases species migration is not an option and some species will face extinction. The risk of increased fires along the boundaries between rainforest and sclerophyll forest is likely to increase putting further pressure on weakened ecosystems (Williams et al. 2001; Hopkins et al. 1993). The physical impact of these changes will include changes to landscapes and their scenic values.

\section{Changes to Visual Environment (Stage 3)}

In some mountain destinations, climate change impacts on the landscape will be visibly noticeable and may affect tourism demand. In other areas change may be more subtle and less obvious. As Williams et al. (2003) observed changes in the Wet Tropics Rainforest will include large-scale loss of biodiversity particularly at the higher end of predicted temperate increases. Loss of biodiversity will include the local extinction of many highly-adapted species of flora and fauna. From a scientific perspective, a future climate change-affected rainforest will be significantly different from the contemporary forest. It will have fewer species, ecosystems are likely to be less-specialized, many native species of plants and animals will have been replaced by invasive species, ecosystems services will have been degraded and many natural boundaries will have changed. It is likely that some areas of rainforest will be in retreat, replaced by open forest while in other areas the rainforest may advance. To the untrained observer, however, the loss of biodiversity will be much less noticeable. The forest will continue to cover the mountain landscapes and will appear to be as luxuriant in the future as it is today. Birds will still be present and their songs will still be audible but the species composition of vertebrates will be different and poorer. This is not likely to cause a significant problem because, as Prideaux and Coghlan (2006) point out, most wildlife viewing currently takes place in the region's zoos rather than in the wild, a consequence of zoos virtually guaranteeing a sighting of a particular species and the nocturnal nature of many of the forest's animals.

\section{Impact on Tourism (Stage 4a)}

Most visitors to the rainforest are urban dwellers who, in general, have little knowledge of rainforest ecosystems and even less local knowledge of species richness and ecosystem complexity, or simplicity. In most cases, visitors will not be able to observe any apparent impacts either from observable changes in the structure and luxuriance of tree growth, loss of vertebrates or visual impacts on major 
landscapes including waterfalls and gorges. Increases in temperature, however, will be noticeable and exacerbate the current discomfort levels in summer although this period coincides with the region's low season.

\section{Tourism Outcomes (Step 5a)}

Previous research into the impact of climate change on mountain destinations by Scott et al. (2007) and Richardson and Loomis (2004) used perception studies to estimate possible future travel patterns to climate-affected regions. In the current study, visitor perceptions of impacts were estimated using a proxy based on visitor reactions to the substantial damage caused to the Wet Tropics Rainforest by Tropical

Cyclone Larry. The advantage of this method is that it allows researchers to investigate visitor reactions to actual rather than scenario-based changes. This category 5 tropical cyclone struck the Queensland coast in April 2006 causing extensive damage to the Wet Tropics rainforests that lay in its path. Damage included loss of canopy cover, loss of branches and the felling of many trees. In the immediate aftermath of the cyclone the area that it had traversed appeared devastated with many trees devoid of leaves and limbs. Fifteen months after the event the canopy cover had partially recovered but the evidence of substantial damage remained visible.

To assess the response of visitors to the quality of the forest, two visitor surveys were conducted, the first 3 months after the cyclone (Falco-Mammone et al. 2006) and the second 15 months after the event (Prideaux and Falco-Mammone 2010). Both surveys were conducted in the Mission Beach area, one of the most heavily cyclone affected areas. In the first survey (Falco-Mammone et al. 2006), 276 people were surveyed and 54\% reported noticing substantial damage to the landscape. Results of the second survey (n=272) (Prideaux and Falco-Mammone 2010), undertaken 12 months after the first survey, found that less than 6\% of respondents reported noticing impacts on the natural landscape. The inference of this research is that to the untrained observer major changes are not noticeable unless the changes to the physical structure of the forest are so extensive that they cannot be ignored. Given that results of the scientific investigation of the forest indicates that the overall look (or scenic values) of the forest will not change greatly. So, the inference that can be drawn is that the level of tourism demand is unlikely to fall from current levels providing that the overall impression to the visitor is of a vibrant forest. Figure 3, illustrates the extensive damage sustained by the rainforest while Figure 4 illustrates the forest 15 months later.

\section{Adaptation Strategies (Stage 6)}

Based on the previous discussion, it does not appear that from the viewpoint of the tourism industry there is a need to implement major adaptation strategies for the Wet Tropics rainforest, except for ongoing monitoring of visitor perceptions of the quality of the forest as it undergoes change. A mechanism for measuring change of this nature has been suggested by McNamara and Prideaux (forthcoming). One possible source of concern that will need attention is adverse media that is likely to be generated as key animal species face imminent extinction. The first example of this occurred in late 2008 when concerns about the possible extinction of the unique White Lemuroid Possum, found only in rainforest above 1000 metres, attracted international media coverage.

\section{Discussion and Conclusion}

The aim of this research was to test the ability of the Climate Change Impact Model to be used as a tool for evaluating the impacts of climate change on mountain tourism destinations. The model incorporates a capacity to synthesize scientific and social science research to produce a tool that may be used for evaluation and planning. In its application to the Wet Tropics the model demonstrated a significant 
capability to synthesize both scientific and social science research to identify potential climate change impacts on the region's tourism industry. Of particular importance is the ability to quantify scientific inputs into specific landscapes and ecosystem changes that can be identified by tourists and therefore measured. As Scott et al. (2007) found, being able to generate realistic scenarios of what a climate change-affected landscape might look like in the future enables the construction of realistic landscape scenarios that can then be measured.

At the destination level, climate change is likely to cause changes to local ecosystems, weather patterns, human use and activity, and have significant impacts on regional economies. For these reasons, it is important to have a capacity such as that demonstrated by the Climate Change Impact Model to measure the type of changes that are likely to occur and assess potential impacts on the tourism industry. Early investigation into probable impacts will provide destination stakeholders with a time buffer that will allow them to develop and implement adaptation strategies of the nature illustrated in Step 6 of the model. In the case of the Wet Tropics rainforest, considerable work has already been undertaken to model how the ecosystem will respond to increasing temperature levels and current evidence suggested that while the biological composition of the Wet Tropics rainforest will change the 'look' of the forest described as tree density, canopy cover and its green colour, is unlikely to change significantly. Drawing on the results of research into visual changes in the structures of the rainforest (Prideaux and Falco-Mammon 2010), it is unlikely that there will be a significant fall in tourism demand for Wet Tropics rainforest experiences. This may not be the case in other mountain destinations where landscape and climatic change may be so extensive that tourism demand is likely to fall.

While testing of the model was limited to one specific destination in this research, it is appropriate to argue that the processes described in Stages 1 to 3 can be generalized to any mountain destination and indeed to non-mountain destinations. The observed changes to the physical environment described in Stage 3aremeasurable and provide a quantifiable basis to measure how tourists will respond in Stage 4a. Once tourist responses are measured in Stage 5, mountain destinations will be able to determine appropriate adaptative strategies in Stage 6.

Based on the evidence presented in this paper, the model exhibits a significant capacity to indicate how climate change will affect specific mountain destinations, provided data on anticipated weather changes and the impact that climate change will have on local ecosystems is available. Once the extent of changes to the landscape and the ecosystem are known, it is possible to test how tourists will react to these changes. On a broader scale, the model may be applied to a large number of ecosystems to produce similar outcomes.

The capacity to measure changes in the ecosystem and how tourists will react to these changes is the key for successful application of the model. However, research of this nature is expensive and has long timeframes. Typically, a series of baseline studies need to be undertaken followed by regular monitoring. Failure to invest in data collection of this nature will produce less than optimal data and hinder long-run assessment. Future research into the impacts of climate change on the tourism industry in other areas should adopt a similar approach using a methodology based on combining scientific and social science research to develop a series of biological and human baselines followed by regular monitoring. This methodology is capable of providing an early warning about the scale of potential climate change impacts allowing stakeholders to respond with appropriate adaption strategies.

Future research priorities in mapping the likely impacts of climate change on mountain destinations should include testing the model in other regions. The most effective approach to undertaking future comparative studies is to standardize the methodology used including both ecosystem research and tourism perception research. The research reported in this paper also highlights the more general need for a closer alignment of social science and scientific research in climate change issues and more broadly in other areas of tourism research. 


\section{Acknowledgements}

The authors acknowledge the financial assistance provided by the Commonwealth Government of Australia’s Marine and Tropical Sciences Research Facility. 


\section{References}

BECKEN, S. and HAY, J. (2007). Tourism and Climate Change: Risks and Opportunities. Clevedon. Channel View Publications. BEEEDIE, P. and HUDSON, S. ( 2003). Emergence of Mountain-Based Adventure Tourism. Annals of Tourism Research 30: 625-643. BEIER, P. and NOSS, R. (1998). Do Habitat Corridors Provide Connectivity? Conservation Biology 12(6): 1241-1252. BENISTON, M. (2003). Climatic Change in Mountain Regions: A Review of Possible Impacts. Climatic Change 59: 5-31. BENTRUPPERBAUMER, J.M., O’FARRELL, S. and RESER, J.P. (2004). Visitor Monitoring System for the Wet Tropics World Heritage Area: Visitor Monitoring Process -From Pre-Destination to Post-Destination (Volume 2). Cairns. Cooperative Research Centre for Tropical Rainforest Ecology and Management (Rainforest CRC). BERNBAUM, E. (1997). Sacred Mountains of the World. London. University of California Press. BRAUN, O., LOHMANN, M., MAKSIMOVIC, O., MEYER, M., MERKOVIC, A., MESSERSCHMIDT, E., RIEDEL, A. and TURNER, M. (1999). Potential Impact of Climate Change Effects on Preferences for Tourism Destinations: A Psychological Pilot Study. Climate Research 11: 247-254.

BUZINDE, C. N., MANUEL-NAVARRETE, D., YOO, E.E. and MORAIS, D. (2010). Tourists' Perceptions in a Climate of Change: Eroding Destinations. Annals of Tourism Research 37(2): 333-354.

BURKI, R., ELSASSER, H., ABEGG, B. and KOENIG, U. (2007). Climate Change and Tourism in the Swiss Alps. In Hall, C. M. and Higham, J. (Eds) Tourism, Recreation and Climate Change. Clevedon. Channel View: 155-164.

DUBOIS, G. and CERON, J-P. (2006). Tourism and Climate Change: Proposals for a Research Agenda. Journal of Sustainable Tourism 14(4): 399-415.

DUKES, J. (2003). Hotter and Weedier? Effects of Climate Change on the Success of Invasive Species. In Green, R., Harley, M., Miles, L., Scharlemann, J., Watkinson, A. and Watts, O. (Eds) Global Climate Change and Biodiversity. Bedfordshire. The RSPB and Tyndall Centre for Climate Change Research.

DWYER, L. and FORSYTH, P. (2008). Climate Change Policies, Long-haul Air Travel and Tourism. In Proceedings of the 18th Annual CAUTHE Conference. Griffith University, Gold Coast, 11-14 February.

EDENSOR, T. (1988). Tourists of the Ra: Performance and Meaning at a Symbolic Sitej. London. Routledge.

ELSASSER, H. and BÜRKI, R. (2002). Climate Change as a Threat to Tourism in the Alps. Climatic Research 20: 253-257.

FALCO-MAMMONE, F., COGHLAN, A. and PRIDEAUX, B. (2006). The Impacts of Cyclone Larry on Tourism in the Mission Beach, Tully and the Atherton Tablelands Region. Cairns. James Cook University.

FRY, C. (2008). The Impact of Climate Change the World's Greatest Challenge in the Twenty-First Century. London. New Holland. GODDE, P., PRICE, M. and ZIMMERMANN, F. (2000). Tourism and Development in Mountain Regions: Moving Forward into the New Millennium. In Godde, P., Price, M. and Zimmermann, F. (Eds) Tourism and Development in Mountain Regions. Wallingford. CABI: $1-26$.

GÖSSLING, S. and SCOTT, D. (2008). Climate Change and Tourism: Exploring Destination Vulnerability. Tourism Review International 12: 1-3.

GÖSSLING, S. and SVENSSON, P. (2006). Tourist Perceptions of Climate Change: A Study of International Tourists in Zanzibar. Current Issues in Tourism 9(4\&5): 419-435.

HALL, M. H. P. and FARGE, D. (2003). Modeled Climate-Induced Glacial Change in Glacier National Park, 1850-2100. Bioscience 53(2): $131-140$.

HALL, C. M. and HIGHAM, J. (2005). Tourism, Recreation and Climate Change. Clevedon. Channel View Publications. HAMILTON, J. and MADDISON, D. and TOL, R. (2005). Effects of Climate Change on International Tourism. Climate Research 29: 245-254. 
HILBERT, D., OSTENDORF, B. and HOPKINS, M. (2001). Sensitivity of Tropical Forests to Climate Change in the Humid Tropics of North Queensland. Austral Ecology 26: 590-603.

HOLDEN, A. (1998). The Use of Visitor Understanding in Skiing Management and Development Decisions at the Cairngorm Mountains, Scotland. Tourism Management 19(2): 145-152.

HOPKINS, M., ASH, J., GRAHAM, A., HEAD, J. and HEWETT, R. (1993). Charcoal Evidence of the Spatial Extent of the Eucalyptus Woodland Expansions and Rainforest Contractions in North Queensland During the Late Pleistocene. Journal of Biogeography 20: 357-372.

INTERGOVERNMENTAL PANEL ON CLIMATE CHANGE (IPCC) (1990). IPCC First Assessment Report. Cambridge. Cambridge University Press.

INTERGOVERNMENTAL PANEL ON CLIMATE CHANGE (IPCC) (1995). IPCC Second Assessment - Climate Change: A Report of the Intergovernmental Panel on Climate Change. Cambridge. Cambridge University Press.

INTERGOVERNMENTAL PANEL ON CLIMATE CHANGE (IPCC) (2001). Climate Change 2001, IPCC Third Assessment Report. Cambridge. Cambridge University Press.

INTERGOVERNMENTAL PANEL ON CLIMATE CHANGE (IPCC) (2007). Summary for Policy Makers. In Solomon, S., Qin, M., Manning, Z. Chen, M., Marquia, K., Averyt, M., Tignor, M. and Miller, H. (Eds) Climate Change 2007: The Physical Science Basis (Contribution of Working Group 1 to the Fourth Assessment Report of the Intergovernmental Panel on Climate Change). Cambridge and New York. Cambridge University Press.

KELLER, F., KIENAST, F. and BEISTON, M. (2000). Evidence of the Response of Vegetation to Environmental Change at High Elevation Sites in the Swiss Alps. Regional Environmental Change 1: 70-77.

KIM, S. and PRIDEAUX, B. (2003). Tourism, Peace, Politics and Ideology: Impacts of the Mt. Gumgang Tour Project in the Korean Peninsula Tourism Management 24(6): 675-685.

KOENIG, U. and ABEGG, B. (1997). Impacts of Climate Change on Winter Tourism in the Swiss Alps. Journal of Sustainable Tourism 5: 46-58.

KREBS, C. (2008). The Ecological World View. Wallingford. CABI.

KROCKENBERGER, A. (2002). A Tropical Rainforest Possum that can't Take the Heat. In Ecology 2002: Handbook of Conference Abstracts of the $2^{\text {nd }}$ joint meeting of the Ecological Society of Australia Inc., and the New Zealand Ecological Society Inc. Cairns Qld 1-6 December. Canberra. Ecological Society of Australia Inc.

KROCKENBERGER, A.K., KITCHING, R.L. and TURTON, S.M. (2003). Environmental Crisis: Climate Change and Terrestrial Biodiversity in Queensland. Cairns. Rainforest CRC.

LOMAN-SCALON, N. (2006). Stakeholder Response Strategies to Climate Change Impacts on the Economic and Environmental Sustainability of Tourism Destinations. Tourism Review International 10: 103-111.

MCKERCHER, B., PRIDEAUX, B., CHEUNG, C. and LAW, R. (2010). Achieving Voluntary Reductions in the Carbon Footprint of Tourism and Climate Change. Journal of Sustainable Tourism 18(3): 297-317.

MCNAMARA, K. and PRIDEAUX, B. (Forthcoming). Planning Nature-based Hiking Trails in a Tropical Rainforest Setting. Asia Pacific Journal of Tourism Research (forthcoming).

MARSTON, R. (2008). Land, Life and Environmental Change in Mountains. Annals of the Association of American Geographers 98: 507-520.

MASON, D. (1999). Spirit of the Mountains Korea's SAN-SHIN and Traditions of Mountain-Worship. Seoul. Hollym.

MATZARAKIS, A. (2002). Examples of Climate Change Research for Tourism Demands. Paper presented at $15^{\text {th }}$ Conference on 
Biometerology and Aerobiology joint with International Congress on Biometerology, $27^{\text {th }}$ Oct -1 Nov 2002. Kansas City. Missouri: 391-392.

MICHAUD, J. and TURNER, S. (2006). Contending Visions of a Hill-station in Vietnam. Annals of Tourism Research 33: 785-808. NYAUPANE, G., MORAIS, D. and DOWLER, L. (2006). The Role of Community Involvement and Number/type of Visitors on Tourism Impacts: A Controlled Comparison of Annapurna, Nepal and Northwest Yunnan, China. Tourism Management 27: $1373-1385$.

PARMESAN, C. and YOHE, G. (2003). A Globally Coherent Fingerprint of Climate Change Impacts Across Natural Systems. Nature 421: 37-42.

PFISHER, R. (2000). Mountain Cultures as a Tourism Resource: Aboriginal Views on the Privilages of Story Telling. In Godde, P., Price, M. and Zimmermann, F. (Eds) Tourism and Development in Mountain Regions. Wallingford. CABI.

PRIDEAUX, B. and FALCO-MAMMONE, F. (2007). Economic Values of Tourism in the Wet Tropics World Heritage Area. Cairns, Australia. James Cook University and Cooperative Research Centre for Tropical Rainforest Ecology and Management.

PRIDEAUX, B. (2009). Resort Destinations: Evolution, Management and Development. Oxford. Butterworth Heinemann.

PRIDEAUX, B. and COGHLAN, A. (2006). Wildlife Tourism in Tropical North Queensland: An Overview of Visitor Preferences for Wildlife Experiences. Tourism Monograph Series No. 3. Cairns. James Cook University.

PRIDEAUX, B. and FALCO-MANNOME (2010). The Impacts of Cyclone Larry on Tourism in the Mission Beach, Tully \& the Atherton Tablelands Region, One Year Later. Cairns. James Cook University.

PRIDEAUX, B., COGHLIN, A. and MCKERCHER, B. (2009). Identifying Tourists’ Likely to Adopt Voluntary Mitigation Activities to Combat Climate Change. Paper presented in Conference on Facing Climate Change and the Global Economic Crisis: Challenges for the Future of Tourism (20-21 November 2009). Bolzano, Italy. EURAC -European Academy.

RICHARDSON, R. and LOOMIS, J. (2004). Adaptive Recreation Planning and Climate Change: A Contingent Visitation Approach. Ecological Economic 50: 83-99.

ROOT, T., PRICE, J., HALL, K., SCHNEIDER, S., ROSENZEIG, C. and POUNDS, J. (2003). Fingerprints of Global Warming on Wild Animals and Plants. Nature 421: 57-60.

SCOTT, D. (2005). Global Environmental Change and Mountain Tourism. In Gössling, S. and Hall, C.M. (Eds) Tourism and Global Environmental Change. London. Routledge: 54-74.

SCOTT, D., JONES, B. and KONOPEK, J. (2007). Implications of Climate and Environmental Change for Nature-based Tourism in the Canadian Rocky Mountains: A Case Study of Waterton Lakes National Park. Tourism Management 28: 570-579.

SCOTT, D., MCBOYLE, G. and MILLS, B. (2003). Climate Change and the Skiing Industry in Southern Ontario (Canada): Exploring the Importance of Snowmaking as a Technical Adaptation. Climate Change 23(2): 171-181.

SHAH, J.J. and NAGPAL, T. (1997). Urban Air Quality Management Strategy in Asia: Kathmandu Valley Report. World Bank Technical Paper No. 378. Washington, DC. World Bank.

SIMMONS, D. and BECKEN, S. (2004). Ecotourism: The Cost of Getting There. In Buckley, R. (Ed) Case Studies in Ecotourism. Wallingford. CABI: 15- 23.

STERN, N. (2006). Stern Review Report on the Economics of Climate Change. Cambridge. Cambridge University Press. STILL, C. J., FOSTER, N.F. and SCHNEIDER, S. H. (1999). Stimulating the Effects of Climate Change on Tropical Montane Cloud Forests. Nature 398: 608-610.

SUPPIAH, R., MACADAM, I. and WHETTON, P. (2007). Climate Change Projections for the Tropical Rainforest Region of North Queensland. Unpublished report to the Marine and Tropical Sciences Research Facility. Reef and Rainforest Research Centre Limited. Cairns.

TURTON, S., HADWEN, V. and WILSON, W. (2009). The Impacts of Climate Change on Australian Tourism Destinations: Developing 
Adaptation and Response Strategies -A Scoping Study. Gold Coast. CRC Sustainable Tourism.

UNTWO (2007). Davos Declaration Climate Change and Tourism: Responding to Global Challenges. Davos. UNWTO/UNEP. URRY, J. (1990). The Tourist Gaze. Sage. London.

WALTHER, G.R., POST, E., CONVEY, P., MENZEL, A., PARMESAN, C., BEEBEE, T.J.C., FROMENTIN, J., HOEGH-GULDBERG, O. and BAIRLEIN, F. (2002). Ecological Responses to Climate Change. Nature 416: 389-396.

WET TROPICS MANAGEMENT AUTHORITY (WTMA) (2007). State of the Wet Tropics Report, 2006-2007. Cairns. WTMA.

WET TROPICS MANAGEMENT AUTHORITY (WTMA) (2008). State of the Wet Tropics Report, 2007-2008. Cairns. WTMA.

WILLIAMS, A., KAROLY, D. and TAPPER, N. (2001). The Sensitivity of Australian Fire Danger to Climate Change. Climate Change 49: 171-191.

WILLIAMS, S., BOLITHO, E. and FOX, S. (2003). Climate Change in Australian Tropical Rainforests: An Impending Environmental Catastrophe.

Proceedings of the Royal Society of London Series B 270: 1887-1892.

ZURICK, D. and KARAN, P. (1999). Himalaya: Life on the Edge of the World. Baltimore. John Hopkins University Press. 
Figure 1. The Six Step Climate Change Impact Model Applied to Mountain Tourism Destinations

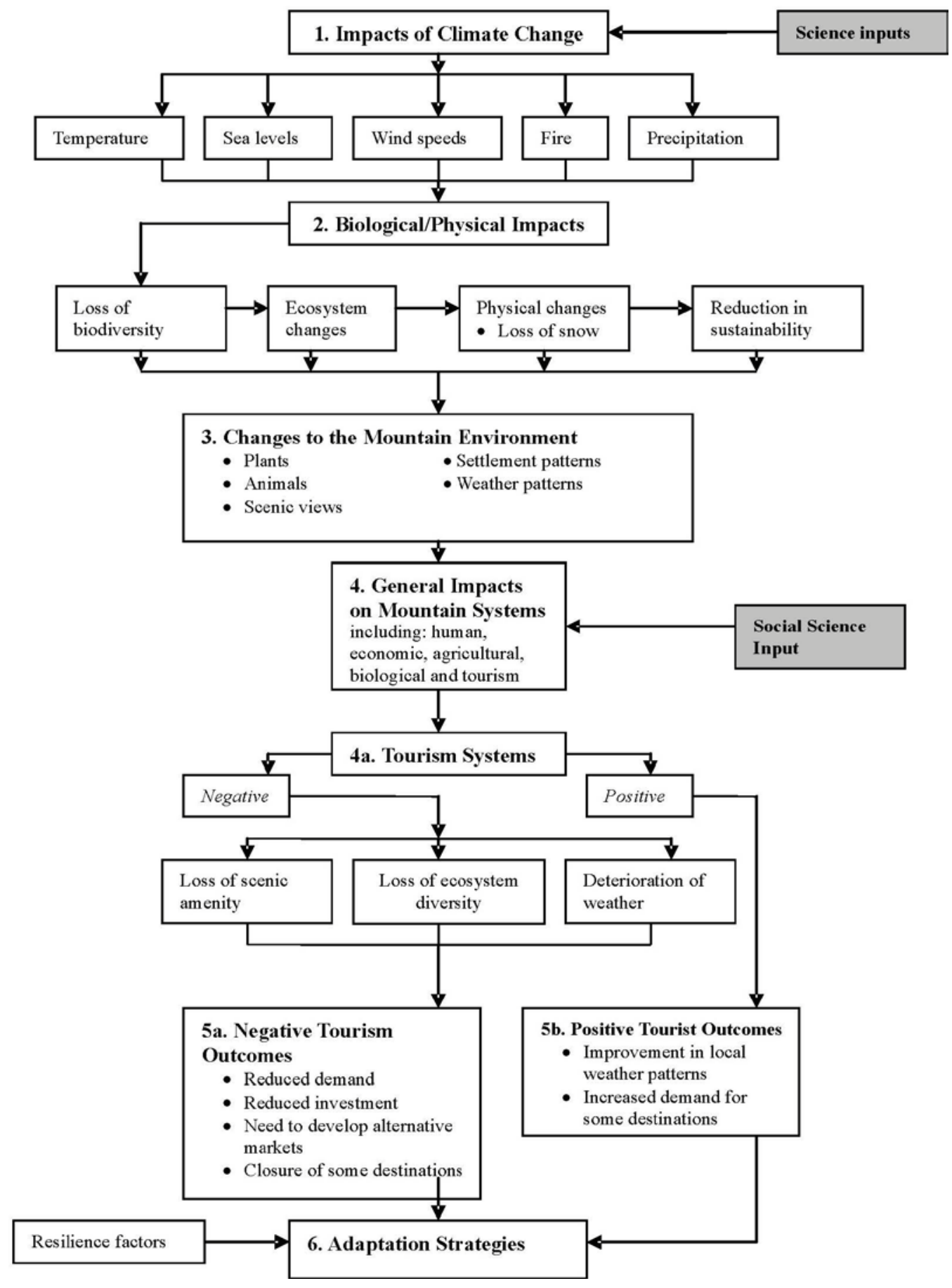


Figure 2. The Decline in Distribution of Species Richness of Regionally Endemic Terrestrial Vertebrates with Increasing Temperature Source: Williams et al. (2003)

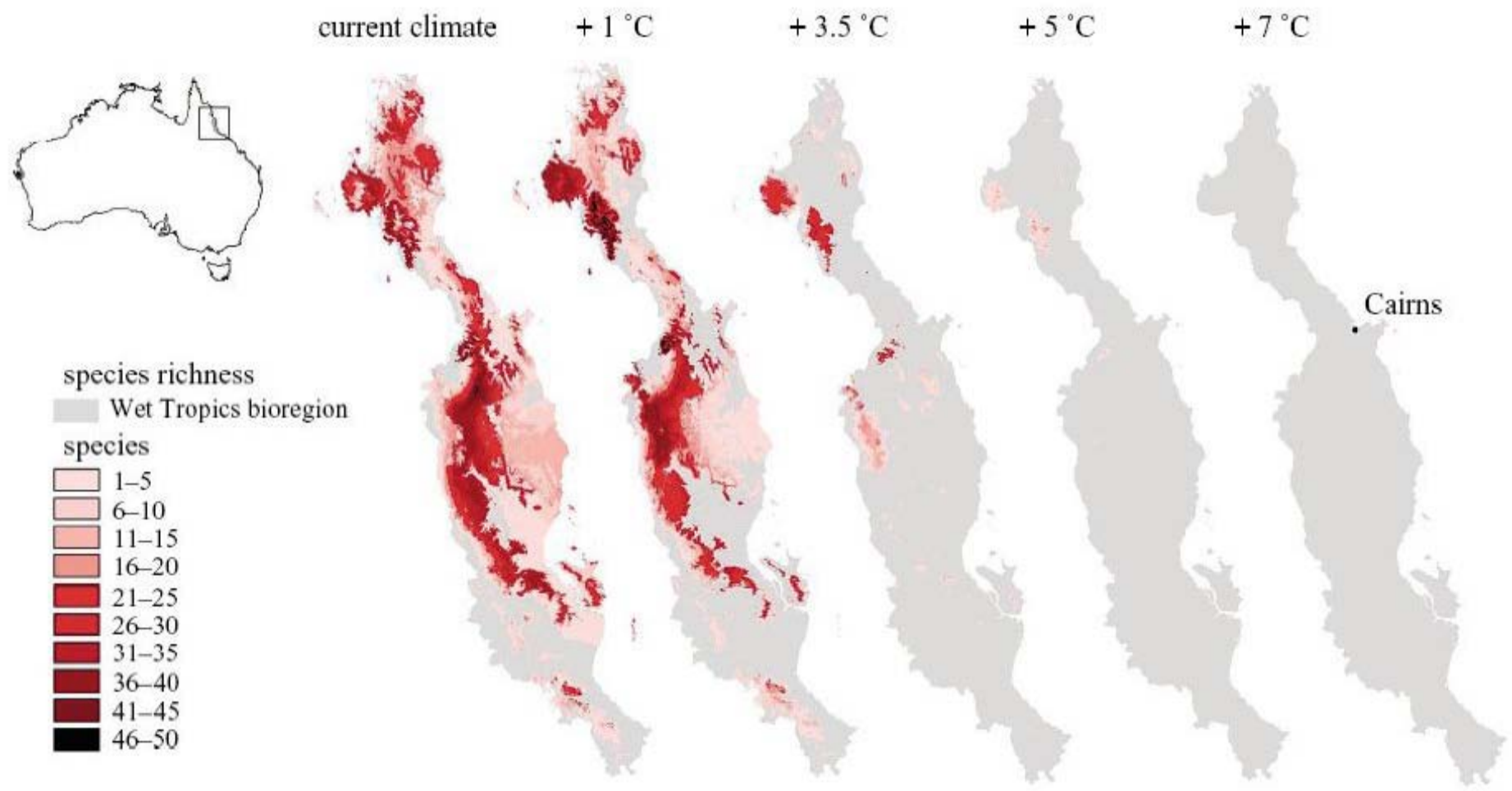

Figure 3. Cyclone Damaged Rainforest in May 2006

(Photo courtesy Bruce Prideaux)

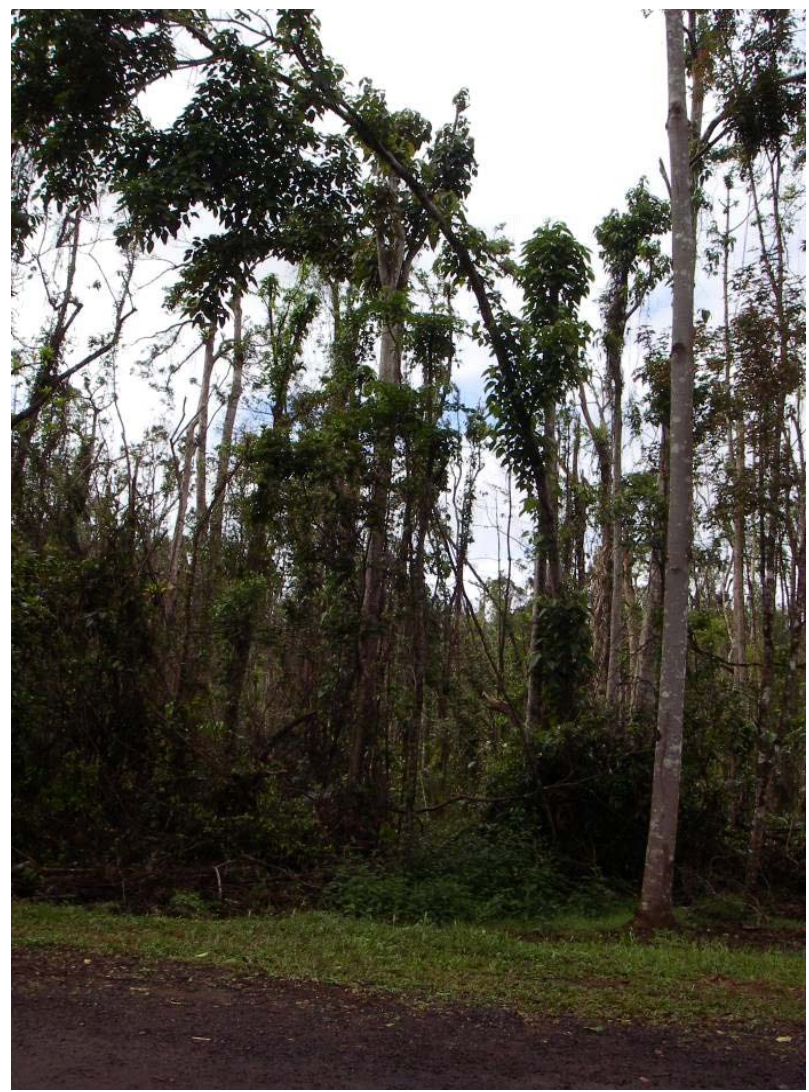


Figure 4. Cyclone Damaged Rainforest 15 Months Later

(Photo courtesy Bruce Prideaux)

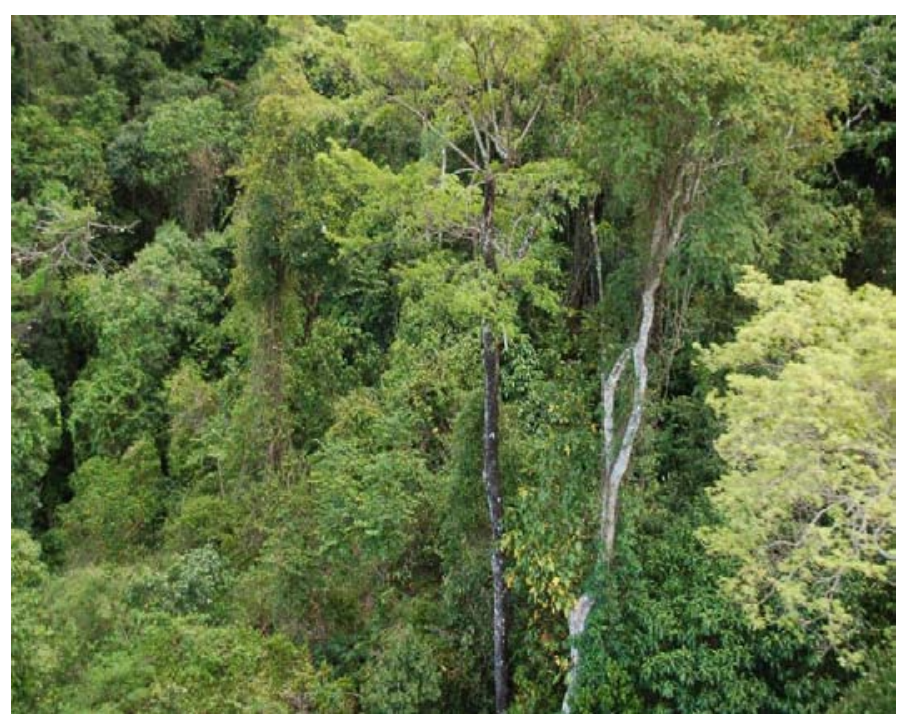

